\title{
The Application of Generational Theory to Digital Content Management
}

\author{
Irina V. Katunina \\ Faculty of Economics \\ Dostoevsky Omsk State University \\ Omsk, Russia \\ i.v.katunina@gmail.com
}

\author{
Valeria E. Kashtanova \\ K2 Marketing \\ Omsk, Russia \\ valeria.e.kashtanova@gmail.com
}

\begin{abstract}
Despite the spread of the generational theory concepts in marketing and management, there is very little empirical research in the field. The study is aimed to investigate whether it is possible to apply the generational perspective to manage digital content. The authors revealed on the base of two experiments that the differences in values, preferences and behavior of Gen $X$ and Gen $Y$ reflect in their reaction on digital content.
\end{abstract}

Keywords: digital content; content management; generational theory; experiment; digital marketing.

\section{INTRODUCTION}

It must be highly improbable to find such a professional in business and management who is not familiar with the terms "Millennials" or "Generation X". Collectively, these labels are known as generational theory that distinguishes different generations in terms of systematic differences in values, preferences and behavior that are stable over time [1].

Since W. Strauss and N. Howe published their book, the generational theory has been influential in the fields of generational studies, marketing, and business management literature. As this seems to be of interest to business leaders who are seeking the way to enter a market or increase the productivity of a workforce, the generational perspective appears to be attractive in managing multigenerational workforce and explaining consumer behavior.

What do millennials want? What defines the generations? How can we best work together?

From this point of view, well-structured digital content management aimed to facilitate content intelligence and deliver frictionless customer experience should be built on the understanding of a customers' generational structure.

But at the same time, there is very little empirical research which supports generational theory. In fact, most of the generalized understanding of different generations (millennials or other groups) is based on assumptions. Additionally, there is some criticism that much of the literature on generational theory issues oversimplifies and overstates the depth of generational gap. Moreover, some scientists concluded that meaningful differences among generations probably do not exist in the workplace [2]..

Taking into consideration these controversial views, the purpose of the study was to consider whether it is possible to apply the generational perspective to manage digital content.

The paper is structured as follows. Firstly, the brief review of the generational perspective and its application is given. Secondly, the authors present research methodology and empirical findings. The paper ends with conclusions and several directions for future research.

\section{LITERATURE REVIEW}

Despite the criticism, a number of recent studies have revealed the use of the generational perspective in explaining such issues as:

- leadership, ethics and human recourse management for different generations [3-5];

- consumer behavior $[6,7]$;

- configuring digital products [8-10].

Nevertheless, one of the problems in the field is connected with the definition of generations.

Strauss and Howe define a social generation as the aggregate of all people born over a span of roughly twenty years or about the length of one phase of life [1].

Deloitte experts [2] shown in their review stress that generational differences in any society are shaped by the political, socioeconomic and cultural events and illustrate how this variability plays out across such countries as India, South Korea, Japan, Russia, Bulgaria, Czech Republic, South Africa, Brazil, and USA. 
In line with the statement that while the idea of generational differences is to some extent universal, the generations are defined specifically to a given society, the authors define Russia's Gen X and Gen Y as follows:

- Gen X (1965-1983) experienced the period of an apparent freefall of society and economy tends to gravitate to roles of being their own boss as well as to become self-taught. Gen X demonstrates informality of views, opinion expression, individualism, search for emotions, self-reliance, independent decision-making and practice orientation.

- Gen Y (1983-2000) being the first truly post-Soviet generation demonstrates a willingness to sacrifice worklife balance in exchange for quick benefits. Gen Y tends to be naive, able to obey, opportunistic, focused on entertainment, they are more theorists and prefer group decision-making.

Keeping these statements in mind, a set of research questions guided the empirical research were formulated. Are there any differences in digital content perception among Gen $\mathrm{X}$ and Gen $\mathrm{Y}$ ? Whether it is possible to manage digital content in accordance with the generational structure of consumers?

\section{RESEARCH METHODOLOGY}

The chosen research design was an experiment (design pretest - post-test experimental and control groups design).

Hypotheses put forward by the authors are as follows:

- Hypothesis 1.1: Gen X is more susceptible to call-toaction digital content than Gen Y.

- Hypothesis 1.2: Gen Y is more susceptible to the influence of viral digital marketing creating a "majority effect" and positioning product as a trend than Gen X.

- Hypothesis 1.3: Gen $X$ is more receptive to media advertising with the banner than Gen Y.

In order to test Hypotheses 1.1 and 1.2, the authors conducted two experiments on the base of two online schools for learning programming languages (Schools A and B).

Both schools have official webpages and public groups in a popular social network offering similar information and educational digital content to their subscribers.

Table 1 demonstrates the generational structure of the public groups.

TABLE II. Generational Structure of the Schools' Public Groups

\begin{tabular}{|l|l|l|l|}
\hline \multirow{2}{*}{ Public Group } & \multicolumn{3}{|l|}{ Proportion of Subscribers, \% } \\
\cline { 2 - 4 } & Gen $\boldsymbol{X}$ & Gen $\boldsymbol{Y}$ & Others \\
\hline School A & 27 & 58 & 15 \\
\hline School B & 30 & 55 & 15 \\
\hline
\end{tabular}

Both public groups have the standard content plan including 3 post per day, 90 posts per month:

- $\quad$ entertaining content $30 \%$ (27 posts per month);
- $\quad$ educational content $40 \%$ (36 posts per month);

- $\quad$ user generated content $20 \%$ (18 posts per month);

- call-to-action content $10 \%$ (9 posts per month).

The first experiment (experiment 1) was conducted in the schools' public groups. Subscribers of School A public group were considered as the experimental group, subscribers of School B public group - as the control group. Table 2 illustrates the experimental design.

TABLE III. Experimental Design

\begin{tabular}{|c|c|c|c|}
\hline Group & Pre-test & Treatment & Post-test \\
\hline Experimental & $\mathrm{O}_{\mathrm{el}}^{\mathrm{a}}$ & yes & $\mathrm{O}_{\mathrm{e} 2}{ }^{\mathrm{b}}$ \\
\hline Control & $\mathrm{O}_{\mathrm{cl}}{ }^{\mathrm{c}}$ & no & $\mathrm{O}_{\mathrm{c} 2}{ }^{\mathrm{d}}$ \\
\hline
\end{tabular}

According to the experimental design, the result of the treatment can be calculated using the formula (1)

$$
\begin{array}{ccc}
\text { Net outcome }= & \left(O_{e 2}-O_{e 1}\right)-\left(O_{c 2}-\right. \\
\left.O_{c 1}\right) . & (1) \\
& \alpha+\beta=\chi . \\
& (1)
\end{array}
$$

Both groups were pretested in terms of their monthly activity (the amount of comments, likes and reposts). The experimental group received the treatment (increasing call-to-action digital content from 9 to 25 posts per month) and both groups are posttested to examine the effects of this manipulation.

The second experiment (experiment 2) was conducted on the basis of an application for the photo and video content exchange through the official webpages of both schools.

The design of the experiment was the same. Both groups were pretested in terms of their monthly purchase activity. The experimental group received the treatment (live user digital content) and both groups are post-tested.

In order to test Hypothesis 1.3, the authors collected data on user activity in terms of impressions, referral traffic and clickthrough rate (CTR) placing a banner advertisement of school A. Click-through rate can be calculated using the formula (2):

CTR $=$ Number of Click-Through / Number of impressions, (2)

$$
\alpha+\beta=\chi \text {. }
$$

Placement channels chosen were a popular social network, a partner application, and a partner website. The format of the posted advertisement included the title, the address, the website, the clickable banner and the description. 


\section{RESULTS}

For experiment 1 , the authors collected data on user activity before and after the introduction of call-to-action content. This kind of content has an "incentive" message, urging the user to perform a specific action. In the case of an experiment, calls-toaction were as follows: leaving a comment, putting a like, making a repost.

Experiment 1 has shown that Gen $\mathrm{X}$ is more susceptible to call-to-action digital content.

According to the results of the pre-test, in the experimental group during the previous month user activity was 109 actions, 65 of which were committed by Gen $X$ and 44 actions by Gen $Y$. The total activity of the control group was 105 actions, 64 and 41 of which were made by representatives of the generations $\mathrm{X}$ and $\mathrm{Y}$ respectively.

During the month of intensive call-to-action digital content for the experimental group, the total number of actions increased by 52 and amounted to 161, of which 101 actions were done by Gen $\mathrm{X}$ and 60 actions by Gen Y. Activity in the control group was observed at the level of 60 actions of Gen $X$ and 45 actions of Gen Y.

Tables 3 and 4 summarize the outcomes of pre- and posttests.

TABLE IV

Outcomes for Gen X (experiment 1)

\begin{tabular}{|l|l|l|l|}
\hline Group & Pre-test & Treatment & Post-test \\
\hline Experimental & $65^{\mathrm{a}}(6+57+2)^{\mathrm{b}}$ & yes & $101(25+71+5)$ \\
\hline Control & $64(3+60+1)$ & no & $60(5+55+0)$ \\
\hline \multicolumn{2}{|r}{$\quad$ b. Comments + Likes + Reposts } \\
\multicolumn{2}{|r}{}
\end{tabular}

TABLE V.

Outcomes for Gen Y (Experiment 1)

\begin{tabular}{|l|l|l|l|}
\hline Group & Pre-test & Treatment & Post-test \\
\hline Experimental & $44(1+43+0)$ & $\mathrm{X}$ & $60(3+57+0)$ \\
\hline Control & $41(0+41+0)$ & & $45(1+44+0)$ \\
\hline
\end{tabular}

According to the formula (1), the net outcome for Gen $\mathrm{X}$ is 40, while for Gen Y is just 12:

$$
\begin{aligned}
& \text { Net outcome }_{e 1}=(101-65)-(60-64)=40 ; \\
& \text { Net outcome }_{c 1}=(60-44)-(45-41)=12 .
\end{aligned}
$$

Thus, Hypothesis 1.1 has been confirmed.

Moreover, calculating the impact of the treatment on the comments, likes and reposts separately (Fig. 1), it was revealed that 11 out of 12 of Gen Y net outcome were "like-actions" while for comments and reposts the impact was 1 and 0 respectively.

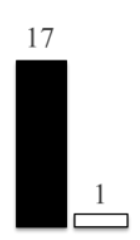

Comments

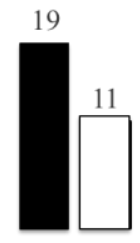

Likes

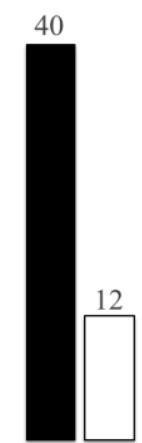

Total activity
Fig. 1. The impact of the treatment on the amount of comments, likes and reposts

This result supports Hypophysis 1.1 as "like-actions" seem to be to some extent impersonal, while comments and reposts are an open and detailed demonstration of an individual point of view or attitude.

In Experiment 2, the authors collected data from the payment systems on the amount of subscriptions sold out through the schools websites. The price of one course subscription is the same for both schools (500 rubles). The pre-test shows that school A had sold out 11 subscriptions during the month before the treatment (4 to Xers and 7 to Yers). During the same period, school B had sold out 43 subscriptions (19 to Xers and 24 to Yers).

The treatment was the launch of live user content such as demonstration of the training process or demonstration of the school's brand in the context of "life style". This live user content was distributed by using geolocation to create the effect of mass use and "trend."

The post-test data collection began two weeks after the launching the viral marketing in school $\mathrm{A}$ in order to obtain sufficient coverage and generate the required amount of content.

Thus, for the month during which the viral marketing was launched in school A, it sold out 7 subscriptions to Xers and 16 to Yers. School B sold 23 and 21 subscriptions respectively. Tables 5 and 6 summarize the outcomes of pre- and post-tests.

TABLE VI.

Outcomes for Gen X (Experiment 2)

\begin{tabular}{|l|l|l|l|}
\hline Group & Pre-test & Treatment & Post-test \\
\hline Experimental & 4 & $\mathrm{X}$ & 7 \\
\hline Control & 19 & & 23 \\
\hline
\end{tabular}

TABLE VII.

Outcomes for Gen Y (Experiment 2)

\begin{tabular}{|l|l|l|l|}
\hline Group & Pre-test & Treatment & Post-test \\
\hline Experimental & 7 & X & 16 \\
\hline Control & 24 & & 21 \\
\hline
\end{tabular}


Experiment 2 has confirmed that Gen $\mathrm{Y}$ is more susceptible to viral digital marketing. According to the formula (1), the net outcome for Gen $\mathrm{X}$ is -1 , while for Gen $\mathrm{Y}$ this indicator is +12 :

$$
\begin{aligned}
& \text { Net outcome }_{\mathrm{e} 2}=(7-4)-(23-19)=-1 ; \\
& \text { Net outcome }_{\mathrm{c} 2}=(16-7)-(21-24)=12 .
\end{aligned}
$$

Thus, Hypothesis 1.2 has also been confirmed.

Finally, the authors examined the data obtained from media advertising on a popular social network, a partner application, and a partner website. To determine how susceptible the representatives of different generations to media advertising, from the data obtained, CTRs for all channels for each generation group were calculated.

The results are presented in Table 7.

\begin{tabular}{|c|c|c|c|c|c|}
\hline \multirow{2}{*}{ Indicator } & \multirow{2}{*}{ Channel } & \multicolumn{3}{|c|}{ Generation } & \multirow{2}{*}{ Total } \\
\hline & & Gen $X$ & Gen Y & Others $^{\mathrm{a}}$ & \\
\hline \multirow{3}{*}{ Impressions } & $\begin{array}{l}\text { Partner } \\
\text { website }\end{array}$ & 9275 & 16526 & 16001 & 41802 \\
\hline & $\begin{array}{l}\text { Social } \\
\text { network }\end{array}$ & 117458 & 192114 & 1901 & 311473 \\
\hline & $\begin{array}{l}\text { Partner } \\
\text { application }\end{array}$ & 6715 & 9536 & 4032 & 20283 \\
\hline \multirow{3}{*}{$\begin{array}{l}\text { Referral } \\
\text { traffic }\end{array}$} & $\begin{array}{l}\text { Partner } \\
\text { website }\end{array}$ & 423 & 396 & 277 & 1296 \\
\hline & $\begin{array}{l}\text { Social } \\
\text { network }\end{array}$ & 857 & 1091 & 8 & 1956 \\
\hline & $\begin{array}{l}\text { Partner } \\
\text { application }\end{array}$ & 107 & 81 & 46 & 234 \\
\hline \multicolumn{2}{|c|}{ Click-through rate, $\%$} & 2.3 & 1.3 & 1.1 & \\
\hline
\end{tabular}

TABLE VIII.

a. Users under the age of 18 and older than 53 as well as those whose age was not identified (unauthorized users)

The advertisements placed on the site and in the partner application were not targeted and were shown to all users. The advertisements placed on the social network were configured to demonstrate to users of 20-50 years old, which explains the relatively low indicator of the "other". The average CTR showing the percentage of users who interacted with the advertisements as well as the total number of users to whom it was demonstrated for Gen X is $2.3 \%$, while for Gen Y it is $1.3 \%$ and "other" is $1.1 \%$. Thus, it can be concluded that Gen $\mathrm{X}$ is more responsive to media advertising than Gen Y. Hypothesis 1.3 has also been confirmed.

\section{CONCLUSIONS AND FUTURE RESEARCH}

The findings contribute to understanding of consumer perception of digital marketing tools in order to form effective programs for managing digital content on the Internet.

It was investigated how the system of values formed in the historical context influences the perception of digital marketing tools. The results confirm the relationship between the key behavioral characteristics of users belonging to different generations and the peculiarities of their behavior in interaction with digital marketing tools.

Experiment 1 has shown that Internet users considered as representatives of generation $\mathrm{X}$ are more susceptible to content such as call-to-action. These people are characterized by a high need for expressing their individuality, they like to show their attitude and express an opinion, while generation $\mathrm{Y}$, on the contrary, strives for unification and imitation, "be with everyone or be alone."

Based on the results of experiment 2, it can be concluded that Gen $\mathrm{Y}$ is more susceptible to the tools of viral marketing than representatives of Gen X, which is dictated by the desire of Gen Y to comply to, to be a part of a specific group ("be in trend") and make decisions based on the opinion of the majority.

Finally, it was concluded that Gen $\mathrm{X}$ is more responsive to media advertising than Gen Y. Gen X is focused on searching information, cognition and action that is also manifested in their consumer behavior within the framework of traditional nondigital marketing.

It should be also noticed that Gen Y has been accumulating its experience in the era of digital and ICT technologies. Growing up in the information garbage, they are used to "filter" incoming information, actively use ad blockers and more often explore the Internet from mobile devices with an adaptive design eliminating side columns where up to $40 \%$ of media advertising is placed.

This allows to conclude that the application of generational theory can indeed underlie the formation of maximally clientoriented promotion programs by identifying the predisposition of specific groups of consumers to various online marketing tools and their effective combination.

The findings of the study provide new challenges for companies operating in a digital world. Further research seems to be focused on developing descriptive patterns of generational consumer behavior for studying (1) advertising placement, (2) user experience for the formation of user interface, and (3) creation of customer journey map to develop an effective integrated digital strategy.

The paper has offered a preliminary results that should be enriched with the longitudinal study within the more prolonged period and within other online businesses. Moreover, in-depth case study analysis would contribute to the understanding how digital content management can be organized from the generational perspective. 


\section{REFERENCES}

[1] Strauss W., Howe N. The fourth turning : an American prophecy. New York: Broadway Books, 1997.

[2] Hole D., Zhong L., Schwartz J. Talking aboutwhose generation? Why western generational models can't account for a global workforce // Deloitte Review. 2010. N 6. P. 83-97.

[3] Anderson H. J., Baur J. E., Griffith J. A. et al. What works for you may not work for (Gen)Me: Limitations of present leadership theories for the new generation // The Leadership Quarterly. 2017. N 28(1). P 245-260. doi:10.1016/J.LEAQUA.2016.08.001.

[4] Welsh D. H. B., Memili E., Rosplock K., J. Roure, and J. L. Segurado, "Perceptions of entrepreneurship across generations in family offices: A stewardship theory perspective // Journal of Family Business Strategy, 2013. Vol. 4, N 3. P. 213-226.

[5] Celikdemir D. Z., Tukel I. Incorporating Ethics into Strategic Management with Regards to Generation Y's view of Ethics // Procedia Social and Behavioral Sciences. 2015. Vol. 207. P. 528-535.

[6] Li X., Li X., Hudson S. The application of generational theory to tourism consumer behavior: An American perspective // Tourism Management. 2013. Vol. 37. P. 147-164. doi: 10.1016/J.TOURMAN.2013.01.015

[7] Huang Q., Lu Y. Generational perspective on consumer behavior: China's potential outbound tourist market // Tourism Management Perspectives. 2017. Vol. 24. P. 7-15.

[8] Boonsiritomachai W., Pitchayadejanant K. Determinants affecting mobile banking adoption by generation $\mathrm{Y}$ based on the Unified Theory of Acceptance and Use of Technology Model modified by the Technology Acceptance Model concept // Kasetsart Journal of Social Sciences. In press. doi:10.1016/J.KJSS.2017.10.005.

[9] Freestone O., Mitchell V. Generation Y attitudes towards E-ethics and Internet-related misbehaviours // Journal of Business Ethics. 2004. Vol. 54, N 2. P. 121-128. doi:10.1007/s10551-004-1571-0.

[10] Kumar A., Lim H. Age differences in mobile service perceptions: comparison of Generation $\mathrm{Y}$ and baby boomers // Journal of Services Marketing. 2008. Vol. 22, N 7. P. 568-577. doi:10.1108/08876040810909695. 